\title{
Strategic Management Tools and Techniques: A Comparative Analysis of Empirical Studies
}

\author{
Albana Berisha Qehaja \\ University of Prishtina, Faculty of Economy, Prishtina, \\ Republic of Kosovo \\ albana.berisha@uni-pr.edu

\section{Enver Kutllovci} \\ University of Prishtina, Faculty of Economy, Prishtina, \\ Republic of Kosovo \\ enver.kutllovci@uni-pr.edu \\ Justina Shiroka Pula \\ University of Prishtina, Faculty of Economy, Prishtina, \\ Republic of Kosovo \\ justina.pula@uni-pr.edu
}

\author{
CroEconSur \\ Vol. 19 \\ No. 1 \\ June 2017 \\ pp. $67-99$
}

Received: January 13, 2017

Accepted: May 11, 2017

Review Article

doi:10.15179/ces.19.1.3

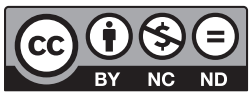

\section{Abstract}

There is no doubt that strategic management tools and techniques are important parts of the strategic management process. Their use in organizations should be observed in a practice-based context. This paper analyzes the empirical studies on the usage of strategic management tools and techniques. Hence, the main aim of this study is to investigate and analyze which enterprises, according to their country development level, use more strategic management tools and techniques and which of these are used the most. Also, this paper investigates which strategic management tools and techniques are used globally according to the results of empirical studies. The study presents a summary of empirical studies for the period 1990-2015. The research results indicate that more strategic tools and techniques are used in developed countries, followed by developing countries and fewest in countries in transition. This study is likely to contribute to the field 
of strategic management because it summarizes the most used strategic tools and techniques at the global level according to varying stages of countries' economic development. Also, the findings from this study may be utilized to maximize the full potential of enterprises and reduce the cases of entrepreneurship failures, through creating awareness of the importance of using strategic management tools and techniques.

Keywords: strategic tools and techniques usage, empirical studies, developed countries, developing countries, countries in transition, global level

JEL classification: O20, O21, M19

\section{"Research is to see what everybody else has seen, and to think what nobody else has thought."}

(Albert Szent-Györgyi)

\section{Introduction}

Strategy is a key concept in the strategic management field. This concept comes from the Greek word strategos, meaning leadership in the military sense: it concerns planning the deployment of resources to achieve certain objectives (Kotler, Berger and Bickhoff, 2015). According to Porter (1991: 97): "Strategy is the act of aligning a company and its environment. That environment, as well as the firm's own capabilities, are subject to change. Thus, the task of strategy is to maintain a dynamic, not a static balance."

Strategic management can be conceptualized as a set of theories and frameworks, supported by tools and techniques, designed to assist managers of organizations in thinking, planning and acting strategically (Stonehouse and Pemberton, 2002). Strategy tool is a generic name for any method, model, technique, tool, technology, framework, methodology or approach used to facilitate strategy 
work (Stenfors et al., 2007). A variety of strategic tools and techniques have been developed to support decision making within strategic management (Ramanujam, Venkatraman and Camillus, 1986; Clark, 1997; Clark and Scott, 1999; Frost, 2003; Gunn and Williams, 2007). These tools are mainly developed by consultants for large international companies (Stenfors et al., 2007). Grint (1997) highlights that at least one new approach for transformation has emerged every year in the last forty years. Clark (1997) emphasizes that strategic management tools and techniques (hereinafter often abbreviated as SMTTs) can be included in all stages of the strategic management process: situation assessment, strategic analysis of options and strategic implementation.

According to Porter (1996: 61): "the quest for productivity, quality and speed has spawned a remarkable number of management tools and techniques... Although the resulting operational improvements have often been dramatic, many companies have been frustrated by their inability to translate those gains into sustainable profitability. And bit by bit, almost imperceptibly, management tools have taken the place of strategy." Accordingly, strategic management has often been criticized on the grounds that it is based upon theoretical principles and not on the realities of management (Berry, 1998). Improving the quality and application of strategic management education is seen as one way to enhance management practice (Baldridge, Floyd and Markóczy, 2004; Bower, 2008; Grant, 2008; Ghoshal and Moran, 1996; Jarzabkowski and Whittington, 2008; Prahalad and Hamel, 1994; Whittington et al., 2003, as cited by Jarzabkowski et al., 2012).

Managers no longer have the luxury of dealing with a few key issues at a time. They must deal with a multitude of issues from different directions simultaneously. Strategic tools and techniques that help managers deal with these complexities and uncertainties will be much sought after (Wright, Paroutis and Blettner, 2013, as cited by Berisha Qehaja, Kutllovci and Shiroka Pula, 2017). Strategic planning may be suitable as a thought process to integrate and provide an organized representation of all of the management steps. But it does not give 
any indication of the extent of the potential success of the chosen strategyit suggests a certainty to decision makers, but it does not guarantee success. Consequently, if they want to get any closer to the issue of a strategy's success, decision makers first need to adopt a diverse range of perspectives by applying strategy tools (Kotler, Berger and Bickhoff, 2015: 24).

The use of SMTTs in organizations should be observed in a practice-based context. Consequently, some questions arise on the topic: Which strategic tools and techniques are used the most, according to the country development level? Which strategic tools and techniques are used the most at the global level, according to empirical studies in countries with different development levels? Hence, the main aim of this study is to investigate and analyze which enterprises, according to their country development level, use more strategic management tools and techniques and which of these are used the most. Also, this paper investigates which strategic management tools and techniques are used globally according to the results of empirical studies.

\section{Theoretical Insights}

The strategic management field has undergone spectacular growth. On the basis of an evolutionary elucidation, Dagnino and Cinici (2016) detect four paradigms of strategy: (a) the structure-conduct performance (SCP) paradigm, (b) the resources-competences-performance (RCP) paradigm, (c) the knowledgecapabilities-performance $(\mathrm{KCP})$ paradigm, and (d) the evolutionary paradigm.

At the end of the 1970s, strategic planning suffered a downturn in popularity and influence. In large part this was due to the inability of strategic planning tools to deliver what was expected of them (Glaister and Falshaw, 1999). According to Barney (1991) and Grant (1991), the development of a resource-based view has played a major role in the renewal of strategic planning practice. Even Glaister and Falshaw (1999) believe that the renewal of strategic planning in the 1990s stemmed from the development of a resource-based view. 
Tools for better planning had begun to emerge before the publication of the classic book by Ansoff Corporate Strategy in 1965 (Hussey, 1997). The list of tools that have been developed and proposed by consultants or academics yet have never been widely adopted is too long to enumerate (Jarzabkowski and Kaplan, 2015). Although there is no definitive list of SMTTs in the literature (Clark, 1997), there have been several attempts to classify them, but these studies are considered secondary. After extensive research into the literature, Lisiński and Šaruckij (2006) also point to a lack of comprehensive studies devoted to the categorization of strategic planning methods. Some authors have presented a number of tools for strategic analysis by specifying them as a guide for managers (Prescott and Grant, 1988; Webster, Reif and Bracker, 1989; Clark, 1997; Vaitkevičius, 2006; Lisiński and Šaruckij, 2006).

Knowledge-based global competition has created a need for purposeful strategy work and effective decision-making processes. Companies thrive on growth and competitive advantage and seek more successful ways of working with and managing knowledge (Stenfors et al., 2007). Wright, Paroutis and Blettner (2013) point out that under increasingly complex and uncertain environments, managers are expected to recognize and embrace a more complicated (not simplified) understanding of (an) emerging world(s), and as such, need at their disposal tools and techniques for better decision making. In these circumstances, companies can benefit more than ever from strategic management, its tools and techniques, as their proper use improves the performance and efficiency of enterprises. According to Afonina and Chalupský (2013), strategic management tools and techniques could bring a lot of benefits for the organizations under the condition that managers have a clear perception/understanding of existing tools and techniques.

There have been many calls from academics to review the role and importance of SMTTs (Frost, 2003; Barney and Clark, 2007; Jarzabkowski et al., 2012; Tassabehji and Isherwood, 2014). Knott (2006: 1091) highlights that the role of SMTTs is: "a guide to thinking and a starting point for structuring strategic 
management activity." Pasanen (2011) emphasizes that the role of SMTTs is to facilitate strategy work, while Webster, Reif and Bracker (1989) point out that the use of SMTTs raises the level of strategic thinking in organizations and the "effectiveness of the strategic planning process". Afonina and Chalupský (2012) stress that SMTTs are various tools that support managers in all stages of strategic management-from strategic analysis to the selection of the strategy and its implementation, in order to improve deficiencies in the organization to achieve better performance.

The results of Jarzabkowski et al. (2012) clearly indicate a strong impact of management education in the workplace practice of business school alumni. Wright, Paroutis and Blettner (2013) probe the question: How useful are the strategic tools we teach in business schools? Their findings are promising in a business school context (prior to the manifestation of practice). Gunn and Williams (2007) find that there is a clear relationship between the educational background of the respondents and their use of strategic tools. Those respondents with master's degrees tend to utilize a grouping of tools commonly associated with those taught in business schools as part of management courses (Gunn and Williams, 2007). Unlike others, Vaitkevičius (2007) finds that managers in Lithuanian organizations define SMTTs incorrectly. According to him, one possible way to explain this could be that knowledge gained through general education is not sufficient to engage in effective strategy development (Berisha Qehaja, Kutllovci and Shiroka Pula, 2017).

The use of strategic tools in organizations, whilst still fundamental to creating and developing strategy, should be viewed from a practice-based perspective (Gunn and Williams, 2007). There are gaps between the theory of how SMTTs should be used and their real usage (how managers use them). Therefore, recently several authors have introduced into the literature a new approach known as "strategy as practice" (Whittington, 1996; 2006; 2012; Jarzabkowski, 2004; 2005; Johnson, 2007; Carter, Clegg and Kornberger 2008; Jarzabkowski and 
Spee, 2009; Golsorkhi et al., 2010; Vaara and Whittington, 2012, as cited by Berisha Qehaja, Kutllovci and Shiroka Pula, 2017).

The benefits of SMTTs enumerated by Frost (2003) include: increasing awareness about the business environment, strategic issues, opportunities and threats which helps reduce the risk involved in making certain decisions; establishing priorities in large, complex companies and providing a framework for evaluating the relative importance of different business portfolios. According to Gunn and Williams (2007), strategic tools can be used to analyze an organization and its environment, or as a mechanism to improve communication, control and coordination. Webster, Reif and Bracker (1989) argue that the use of SMTTs will increase the analytical and diagnostic skills of managers, while Pasanen (2011) emphasizes that efficiency is the most important advantage of using SMTTs. According to Frost (2003), strategic management techniques may also aid the presentation of complex issues, and may be seen as valuable communication devices, in addition to their analytical role. Also according to him, it often becomes possible to reduce many pages of a narrative plan to one or two diagrams that result from the use of some of the techniques (Berisha Qehaja, Kutllovci and Shiroka Pula, 2017).

Gunn and Williams (2007) have argued that the understanding of strategic tools usage is important for three main reasons. First, it indicates the motivations of managers when using strategic tools. Second, it will be suggestive of the dissemination processes underpinning the application of tools. Third, it assists academics and practitioners in moving away from a normative, rational approach to more humanistic, practice-based approaches to the understanding of tool usage.

\section{Methodology}

The study is based on a systematic review of empirical studies on the usage of strategic management tools and techniques. According to Geddes and Carney 
(2002), systematic reviews (or overviews) are syntheses of primary research studies that use (and describe) specific, explicit and therefore reproducible methodological strategies to identify, assemble, critically appraise and synthesize all relevant issues on a specific topic.

The main methods used for synthesizing and comparing empirical studies were textual narrative synthesis and comparative analysis. Textual narrative synthesis can bring together broad knowledge from a variety of methodologies and approaches (Bélanger, Rodríguez and Groleau, 2011). This approach relies primarily on the use of words and text to summarize and explain the findings of the synthesis (Popay et al., 2006). Furthermore, according to Popay et al. (2006), there are four main elements of narrative synthesis: (1) developing a theory of how the intervention works, why and for whom; (2) developing a preliminary synthesis; (3) exploring relationships within and between studies; and (4) assessing the robustness of the synthesis. We then followed these steps to conduct a narrative synthesis for this study.

It should be noted that according to Popay et al. (2006), most straightforwardly robustness can be used to refer to the methodological quality of the primary studies included in the review and/or the trustworthiness of the product of the synthesis process. Thus, all primary studies included in this review are published in prominent scientific journals and their main findings are carefully synthesized.

This study included 27 full articles for a usage review of SMTTs. We used Google Scholar to search the terms strategic management tools and techniques, strategic planning tools and techniques, strategy tools, usage, use and empirical findings. It resulted with a lot of articles on theoretical insights into SMTTs, as well as certain articles focused on a particular tool or technique usage, but we decided to select only the articles about strategic tools and techniques usage, as empirical evidence in different countries. After we selected the articles, we extracted the relevant data from these studies. Additionally, a limited search was undertaken to identify any new study published since the original review was undertaken. 
Therefore, study characteristics, context and the main findings are reported according to a tabulation, and similarities and differences are compared across studies. We have also organized the included studies, clustering them according to country development level and empirical studies conducted on the global level.

This paper in particular has examined the most used SMTTs resulting from all these empirical studies. In order to make an adequate comparison of the results of these studies, they are divided into studies by country development level (developed countries, developing countries and economies in transition) and by enterprise size (different sized enterprises, large enterprises, small and medium enterprises). Two articles were excluded as they did not provide any information about the size and sector of enterprises, but they are included for the analysis of empirical studies in countries with different development levels (global level).

\section{Results and Discussion}

Generally there is a lack of empirical research on the usage of SMTTs. In the available studies, SMTT usage has been analyzed by different researchers. Some have contributed by determining and classifying them, some have investigated which SMTTs are used to a greater extent in different types and sizes of enterprises, while others have investigated the degree of their utilization and effects.

Nevertheless, the usage of SMTTs is not hashed out enough by academics and practitioners. According to Clark (1997) and Gunn and Williams (2007), there is a lack of studies on the usage of SMTTs in enterprises. Elbanna (2008) emphasizes that the majority of studies are conducted in developed countries and few of them in developing countries. Aldehayyat and Anchor (2009) point out that strategy researchers have paid little attention to the study of SMTT usage. Frost (2003) emphasizes that the absence of a strong focus on tools within the strategic management discipline can be partially attributed to the secondary role that they serve. 
Most of the studies support the use of SMTTs as an important part of strategic planning by examining SMTTs as a part of the strategic planning process. Unlike others, Elbanna (2008) argues that some enterprises may use some of the strategic planning tools while having no written strategic plans. Also, according to Šuklev and Debarliev (2012), the formality of strategic planning and the use of strategic planning techniques might be two different dimensions of strategic planning effectiveness, which should be investigated separately.

The empirical studies by their approach and focus are mainly divided as follows: (a) SMTT studies as part of the strategic planning process, (b) focused studies on the usage of SMTTs, and (c) SMTT classification studies.

Empirical studies have explored the application of SMTTs in different countries and enterprises. The following summarizes these studies:

- Studies in developed countries: Clark (1997); Glaister and Falshaw (1999); Stonehouse and Pemberton (2002); Gunn and Williams (2007); Vaitkevičiu (2007); Stenfors et al. (2007); Pasanen (2011); Afonina and Chalupský (2013); Gică and Balint (2012); Nedelko, Potocan and Dabic (2015); Afonina (2015).

- Studies in developing countries: Ghamdi (2005); Dincer, Tatoglu and Glaister (2006); Elbanna (2007); Aldehayyat and Anchor (2009); Aldehayyat, Al Khattab and Anchor (2011); Kalkan and Bozkurt (2013); Rajasekar and Al Raee (2014).

- Studies in countries in transition: Kume and Leskaj (2009); Šuklev and Debarliev (2012).

- Studies in countries with different development levels (global level): Rigby (1993); Frost (2003); Tapinos (2005); O’Brien (2009); Glaister et al. (2009); Tassabehji and Isherwood (2014); Rigby and Bilodeau (2015). 
It should be noted that these studies have used various lists of SMTTs in their research. Table 1 summarizes the key outcomes of empirical studies on the use of SMTTs in the period 1990-2015.

Table 1: A Tabulation of Empirical Studies on the Usage of SMTTs and Their Main Outcomes

\begin{tabular}{|c|c|c|c|c|}
\hline $\begin{array}{l}\text { Author and } \\
\text { year }\end{array}$ & Country & $\begin{array}{l}\text { Industry } \\
\text { and size of } \\
\text { enterprises }\end{array}$ & $\begin{array}{l}\text { Sample size } \\
\text { received/sent }\end{array}$ & The most used SMTTs ${ }^{1}$ \\
\hline Rigby (1993) & $\begin{array}{l}\text { North and South } \\
\text { America, Europe, } \\
\text { Asia and Africa }\end{array}$ & $\mathrm{DSE}^{2}, \mathrm{DS}^{3}$ & - & $\begin{array}{l}\text { Mission statement, customer } \\
\text { satisfaction, total quality management } \\
\text { (TQM), competitor profiling, } \\
\text { benchmarking }\end{array}$ \\
\hline Clark (1997) & $\begin{array}{l}\text { UK and New } \\
\text { Zealand }\end{array}$ & DSE, DS & $\begin{array}{l}\text { UK: } N= \\
61 / 1200 \\
N Z: N= \\
138 / 400\end{array}$ & $\begin{array}{l}\text { SWOT analysis, focused groups, } \\
\text { budgeting, Porter's five forces analysis, } \\
\text { PEST analysis }\end{array}$ \\
\hline $\begin{array}{l}\text { Glaister and } \\
\text { Falshaw } \\
(1999)\end{array}$ & UK & DSE, DS & $\mathrm{N}=113 / 500$ & $\begin{array}{l}\text { "What-if" analysis, key success factors } \\
\text { analysis, financial competitor analysis, } \\
\text { SWOT analysis }\end{array}$ \\
\hline $\begin{array}{l}\text { Stonehouse } \\
\text { and } \\
\text { Pemberton } \\
(2002)\end{array}$ & UK & $\begin{array}{l}\text { DSE, PS } \\
\text { production, } \\
\text { service }\end{array}$ & $\mathrm{N}=159$ & $\begin{array}{l}\text { Business financial analysis, SWOT } \\
\text { analysis, key competencies, } \\
\text { organizational culture, benchmarking }\end{array}$ \\
\hline Frost (2003) & $\begin{array}{l}\text { Western Australia, } \\
\text { Singapore, } \\
\text { Hong Kong and } \\
\text { Malaysia }\end{array}$ & SME & $\mathrm{N}=331 / 783$ & $\begin{array}{l}\text { SWOT analysis, PEST analysis, } \\
\text { budgeting }\end{array}$ \\
\hline $\begin{array}{l}\text { Ghamdi } \\
(2005)\end{array}$ & Saudi Arabia & $\mathrm{N} / \mathrm{I}, \mathrm{N} / \mathrm{I}$ & $\mathrm{N}=72$ & $\begin{array}{l}\text { Key success factors analysis, } \\
\text { benchmarking, "what-if" analysis }\end{array}$ \\
\hline $\begin{array}{l}\text { Tapinos } \\
(2005)\end{array}$ & $\begin{array}{l}42 \text { countries, } \\
\text { including: UK, } \\
\text { Singapore, China, } \\
\text { USA, Greece, etc. }\end{array}$ & DSE, DS & $\mathrm{N}=428 / 4000$ & $\begin{array}{l}\text { SWOT analysis, benchmarking, } \\
\text { cost-benefit analysis, key capability } \\
\text { analysis, risk analysis }\end{array}$ \\
\hline $\begin{array}{l}\text { Dincer, } \\
\text { Tatoglu and } \\
\text { Glaister } \\
(2006)\end{array}$ & Turkey & $\begin{array}{l}\mathrm{LE}^{5} \\
\text { production, } \\
\text { service }\end{array}$ & $\mathrm{N}=135 / 638$ & $\begin{array}{l}\text { SWOT analysis, scenario analysis, } \\
\text { financial competitor analysis }\end{array}$ \\
\hline $\begin{array}{l}\text { Gunn and } \\
\text { Williams } \\
(2007)\end{array}$ & UK & DSE, DS & $\mathrm{N}=149 / 800$ & $\begin{array}{l}\text { SWOT analysis, benchmarking, key } \\
\text { success factors analysis }\end{array}$ \\
\hline
\end{tabular}

1 The most used tools have been derived from the empirical results of different studies. The number of tools defined as the most commonly used varies from study to study.

2 Different sized enterprises.

3 Different sectors.

4 Particular sector/s.

5 Large enterprises. 


\begin{tabular}{|c|c|c|c|c|}
\hline $\begin{array}{l}\text { Elbanna } \\
(2007)\end{array}$ & Egypt & DSE, DS & $\mathrm{N}=120 / 350$ & $\begin{array}{l}\text { Financial statements such as cash } \\
\text { flow, income and budgeting, cost- } \\
\text { benefit analysis, SWOT analysis, } \\
\text { competitor analysis, portfolio } \\
\text { analysis, benchmarking, key success } \\
\text { factors analysis }\end{array}$ \\
\hline $\begin{array}{l}\text { Vaitkevičius } \\
(2007)\end{array}$ & Lithuania & DSE, DS & $\mathrm{N}=216 / 436$ & SWOT analysis \\
\hline $\begin{array}{l}\text { Stenfors et al. } \\
(2007)\end{array}$ & Finland & LE, DS & $\mathrm{N}=182 / 500$ & $\begin{array}{l}\text { SWOT analysis, spreadsheets } \\
\text { applications, balanced scorecard, risk } \\
\text { analysis }\end{array}$ \\
\hline $\begin{array}{l}\text { Kume and } \\
\text { Leskaj (2009) }\end{array}$ & Albania & DSE, DS & $\mathrm{N}=230$ & $\begin{array}{l}\text { SWOT analysis, mathematical and } \\
\text { statistical methods, Porter's five forces } \\
\text { analysis, value chain analysis }\end{array}$ \\
\hline $\begin{array}{l}\text { Aldehayyat } \\
\text { and Anchor } \\
(2009)\end{array}$ & Jordan & DSE, DS & $\mathrm{N}=83 / 203$ & $\begin{array}{l}\text { Business financial analysis, PEST } \\
\text { analysis, Porter's five forces analysis, } \\
\text { key success factors analysis }\end{array}$ \\
\hline $\begin{array}{l}\text { O’Brien } \\
(2009)\end{array}$ & $\begin{array}{l}\text { UK, Europe, } \\
\text { USA, Australia, } \\
\text { New Zealand, } \\
\text { Africa, etc. }\end{array}$ & $\mathrm{N} / \mathrm{I}, \mathrm{N} / \mathrm{I}$ & $\mathrm{N}=143 / 883$ & $\begin{array}{l}\text { Forecasting, business financial } \\
\text { analysis, project management, } \\
\text { brainstorming, SWOT analysis, } \\
\text { balanced scorecard, benchmarking }\end{array}$ \\
\hline $\begin{array}{l}\text { Glaister et al. } \\
(2009)\end{array}$ & UK and Turkey & DSE, DS & $\begin{array}{l}\mathrm{UK}: \mathrm{N}= \\
113 / 500 \\
\mathrm{~T}: \mathrm{N}= \\
135 / 638\end{array}$ & $\begin{array}{l}\text { UK: "what-if" analysis, key success } \\
\text { factors analysis, financial competitor } \\
\text { analysis, SWOT analysis } \\
\text { Turkey: economic forecasting models, } \\
\text { SWOT analysis, scenario analysis }\end{array}$ \\
\hline $\begin{array}{l}\text { Pasanen } \\
(2011)\end{array}$ & Finland & $\begin{array}{l}\text { SME, } \\
\text { production, } \\
\text { service }\end{array}$ & $\mathrm{N}=143$ & $\begin{array}{l}\text { Business strategies, vision and mission } \\
\text { statements, strategic alliances, growth } \\
\text { strategies, SWOT analysis }\end{array}$ \\
\hline $\begin{array}{l}\text { Aldehayyat, } \\
\text { Al Khattab } \\
\text { and Anchor } \\
(2011)\end{array}$ & Jordan & DSE, hotels & $\mathrm{N}=40 / 60$ & $\begin{array}{l}\text { Business financial analysis, SWOT } \\
\text { analysis, PEST analysis, Porter's five } \\
\text { forces analysis }\end{array}$ \\
\hline $\begin{array}{l}\text { Afonina and } \\
\text { Chalupský } \\
(2013)\end{array}$ & Czech Republic & DSE, DS & $\mathrm{N}=74$ & $\begin{array}{l}\text { SWOT analysis, customer } \\
\text { satisfaction, price analysis, analysis of } \\
\text { views and employee attitudes, cost- } \\
\text { benefit analysis, analysis of employee } \\
\text { satisfaction, analysis of customer } \\
\text { complaints, Porter's five forces } \\
\text { analysis, PEST analysis }\end{array}$ \\
\hline $\begin{array}{l}\text { Gică and } \\
\text { Balint (2012) }\end{array}$ & Romania & SME, DS & $\mathrm{N}=200$ & $\begin{array}{l}\text { SWOT analysis, pessimistic and } \\
\text { optimistic scenarios }\end{array}$ \\
\hline $\begin{array}{l}\text { Suklev and } \\
\text { Debarliev } \\
(2012)\end{array}$ & Macedonia & DSE, DS & $\mathrm{N}=212 / 350$ & - \\
\hline $\begin{array}{l}\text { Kalkan and } \\
\text { Bozkurt } \\
(2013)\end{array}$ & Turkey & SME, DS & $\mathrm{N}=192$ & $\begin{array}{l}\text { Strategic planning, human resources } \\
\text { analysis, TQM, customer relationship } \\
\text { management (CRM), vision and } \\
\text { mission statements, PEST analysis, } \\
\text { benchmarking }\end{array}$ \\
\hline $\begin{array}{l}\text { Tassabehji } \\
\text { and } \\
\text { Isherwood } \\
(2014)\end{array}$ & $\begin{array}{l}47 \text { countries, } \\
\text { including: } \\
\text { Europe, USA, } \\
\text { Canada, India, } \\
\text { etc. }\end{array}$ & DSE, DS & $\mathrm{N}=458$ & $\begin{array}{l}\text { SWOT analysis, financial forecasting, } \\
\text { vision and mission statements, } \\
\text { scenario planning, value chain } \\
\text { analysis }\end{array}$ \\
\hline
\end{tabular}




\begin{tabular}{|c|c|c|c|c|}
\hline $\begin{array}{l}\text { Rajasekar } \\
\text { and Al Raee } \\
(2014)\end{array}$ & Oman & DSE, DS & $\mathrm{N}=20 / 63$ & $\begin{array}{l}\text { Benchmarking, stakeholder analysis, } \\
\text { SWOT analysis }\end{array}$ \\
\hline $\begin{array}{l}\text { Nedelko, } \\
\text { Potocan and } \\
\text { Dabic }(2015)\end{array}$ & $\begin{array}{l}\text { Slovenia and } \\
\text { Croatia }\end{array}$ & DSE, DS & $\begin{array}{l}S: N= \\
155 / 750 \\
C: N= \\
185 / 750\end{array}$ & $\begin{array}{l}\text { S: outsourcing, benchmarking, } \\
\text { key competencies, knowledge } \\
\text { management, TQM, etc. } \\
\text { C: vision and mission statements, } \\
\text { benchmarking, key competencies, } \\
\text { CRM, customer segmentation, etc. }\end{array}$ \\
\hline $\begin{array}{l}\text { Afonina } \\
(2015)\end{array}$ & Czech Republic & DSE, DS & $\mathrm{N}=91$ & $\begin{array}{l}\text { SWOT analysis, customer } \\
\text { satisfaction, price analysis, cost- } \\
\text { benefit analysis, market share analysis, } \\
\text { etc. }\end{array}$ \\
\hline $\begin{array}{l}\text { Rigby and } \\
\text { Bilodeau } \\
(2015)\end{array}$ & $\begin{array}{l}\text { Over } 70 \text { countries } \\
(5 \text { continents })\end{array}$ & DSE, DS & $\mathrm{N}=13,000$ & $\begin{array}{l}\text { CRM, benchmarking, employee } \\
\text { engagement surveys, strategic } \\
\text { planning, outsourcing, balanced } \\
\text { scorecard, etc. }\end{array}$ \\
\hline
\end{tabular}

Source: Authors' calculations.

\section{Empirical studies by country development level and enterprise size}

For purposes of this study, the classification of countries is based on the World Bank report (2014) World Economic Situation and Prospects. Figure 1 shows the number of empirical studies by country development level and time period.

The chart in Figure 1 indicates that the most studies on the use of SMTTs are conducted in developed countries, followed by developing countries. After them come studies in various countries with different development levels. However, it seems that there is a lack of this type of research studies in countries in transition.

According to Berisha and Shiroka Pula (2015), economic literature contains major differences in the definition of small and medium enterprises. Statistical agencies, international organizations and governments of independent countries emerge with different definitions and categorizations for businesses which do not reflect the differences between them. 
Figure 1: Empirical Studies by Country Development Level

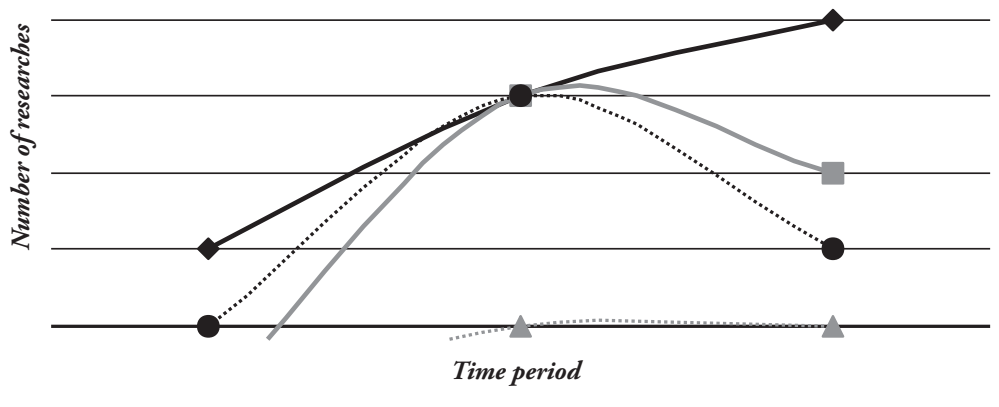

$\sim$ Developed countries

Developing countries

Countries in transition

...... Developed countries, developing countries and countries in transition

Source: Authors' calculations.

Studies on the use of SMTTs are conducted primarily in enterprises of different sizes and different sectors, followed by studies in SMEs and different sectors. After them come studies that did not specify the enterprise size nor the sector, and finally come those in SMEs and particular sectors. The fewest studies are focused on large enterprises (all sectors) and DSEs (particular sectors).

Of all the studies summarized in Table 1, only four of them have analyzed the usage of SMTTs in particular in one or two specific sectors.

The diagram in Figure 2 provides a summary of the empirical studies by enterprise size ${ }^{6}$. 
Figure 2: Empirical Studies by Enterprise Size

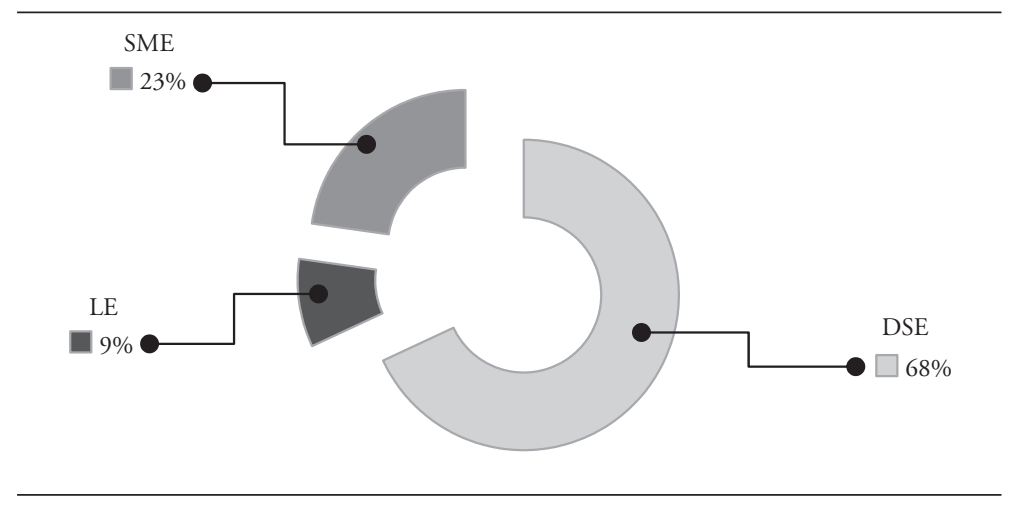

Source: Authors' calculations.

Moreover, the diagram in Figure 2 points out that empirical studies on the usage of SMTTs mainly have been conducted in enterprises of different sizes (68 percent), followed by SMEs ( 23 percent), while the fewest have been conducted in large enterprises (9 percent).

Considering the results of empirical studies on the most used SMTTs, these are generally analyzed by the country development level and enterprise size. Nevertheless, it should be noted that this analysis did not include the results of empirical studies by Ghamdi (2005) and O'Brien (2009) because we did not have information about the size of enterprises in their research. Additionally, the analysis of SMTT usage in developed countries has included empirical studies that have made a comparative analysis between two countries, as researched countries belong to the category of developed countries (Clark, 1997; Nedelko, Potocan and Dabic, 2015). 
Table 2: Empirical Results by the Country Development Level and Enterprise Size

\begin{tabular}{|c|c|c|c|}
\hline \multirow{2}{*}{$\begin{array}{l}\text { Country } \\
\text { development } \\
\text { level }\end{array}$} & \multicolumn{3}{|c|}{ Enterprise size } \\
\hline & DSE & LE & SME \\
\hline $\begin{array}{l}\text { Developed } \\
\text { countries }\end{array}$ & $\begin{array}{l}\text { SWOT analysis } \\
\text { Benchmarking } \\
\text { Customer satisfaction } \\
\text { Key success factors analysis } \\
\text { Price analysis } \\
\text { Key competencies } \\
\text { Cost-benefit analysis } \\
\text { Porter's five forces analysis } \\
\text { PEST analysis } \\
\text { "What-if" analysis } \\
\text { Vision and mission statements } \\
\text { Outsourcing } \\
\text { Focused groups } \\
\text { Budgeting } \\
\text { Competitor financial analysis } \\
\text { Analysis of views and employee attitudes } \\
\text { Knowledge management } \\
\text { CRM } \\
\text { Analysis of customer complaints } \\
\text { TQM } \\
\text { Customer segmentation } \\
\text { Market share analysis }\end{array}$ & $\begin{array}{l}\text { SWOT analysis } \\
\text { Spreadsheets } \\
\text { applications } \\
\text { Balanced } \\
\text { scorecard } \\
\text { Risk analysis }\end{array}$ & $\begin{array}{l}\text { SWOT analysis } \\
\text { Business strategies } \\
\text { Vision and mission } \\
\text { statements } \\
\text { Pessimistic and } \\
\text { optimistic scenarios } \\
\text { Strategic alliances } \\
\text { Growth strategies } \\
\text { Business financial } \\
\text { analysis }\end{array}$ \\
\hline $\begin{array}{l}\text { Developing } \\
\text { countries }\end{array}$ & $\begin{array}{l}\text { Business financial analysis } \\
\text { SWOT analysis } \\
\text { PEST analysis } \\
\text { Porter's five forces analysis } \\
\text { Benchmarking } \\
\text { Stakeholder analysis } \\
\text { Key success factors analysis }\end{array}$ & $\begin{array}{l}\text { SWOT analysis } \\
\text { Scenario analysis } \\
\text { Competitor } \\
\text { financial analysis }\end{array}$ & $\begin{array}{l}\text { Strategic planning } \\
\text { Business financial } \\
\text { analysis } \\
\text { Cost-benefit analysis } \\
\text { Human resources } \\
\text { analysis } \\
\text { SWOT analysis } \\
\text { TQM } \\
\text { CRM } \\
\text { Competitor profiling } \\
\text { Vision and mission } \\
\text { statements } \\
\text { Portfolio analysis } \\
\text { Benchmarking } \\
\text { PEST analysis } \\
\text { Key success factors } \\
\text { analysis }\end{array}$ \\
\hline $\begin{array}{l}\text { Transition } \\
\text { countries }\end{array}$ & $\begin{array}{l}\text { SWOT analysis } \\
\text { Mathematical and statistical methods } \\
\text { Porter's five forces analysis } \\
\text { Value chain analysis }\end{array}$ & - & - \\
\hline $\begin{array}{l}\text { Developed } \\
\text { countries, } \\
\text { developing } \\
\text { countries and } \\
\text { countries in } \\
\text { transition }\end{array}$ & $\begin{array}{l}\text { SWOT analysis } \\
\text { "What-if" analysis } \\
\text { Vision and mission statements } \\
\text { Benchmarking } \\
\text { Financial forecasting } \\
\text { Economic forecasting models } \\
\text { Key success factors analysis } \\
\text { Customer satisfaction } \\
\text { Cost-benefit analysis } \\
\text { TQM } \\
\text { Key capabilities } \\
\text { Value chain analysis } \\
\text { Risk analysis } \\
\text { Competitor profiling }\end{array}$ & - & $\begin{array}{l}\text { SWOT analysis } \\
\text { PEST analysis } \\
\text { Budgeting }\end{array}$ \\
\hline
\end{tabular}

Source: Authors' construction. 


\section{Developed countries}

It is noted that enterprises of different sizes (DSEs) in developed countries use a wider variety of SMTTs (a total of 22 SMTTs resulted as the most used) than large enterprises (LEs) (a total of four SMTTs) and SMEs (a total of seven SMTTs). It should also be noted that in all types of enterprises in developed countries SWOT analysis resulted as the most used tool.

The ten most used SMTTs according to the results of several studies conducted in developed countries (Clark, 1997; Glaister and Falshaw, 1999; Stonehouse and Pemberton, 2002; Gunn and Williams, 2007; Vaitkevičiu, 2007; Stenfors et al., 2007; Pasanen, 2011; Afonina and Chalupský, 2013; Gică and Balint, 2012; Nedelko, Potocan and Dabic, 2015; Afonina, 2015) are: SWOT analysis, benchmarking, key competencies, customer satisfaction, key success factors analysis, price analysis, cost-benefit analysis, Porter's five forces analysis, PEST analysis and "what-if" analysis.

\section{Developing countries}

The results showed that the diversity of used tools is higher in SMEs (13) than in LEs (3) and DSEs (7). Again, SWOT analysis has resulted as one of the most used tools regardless of the enterprise size. Apart from this tool, no other similarities were noticed in the used tools in LEs and SMEs. However, similar results were noticed for DSEs and SMEs. The most used tools in DSEs and SMEs in developing countries appeared to be: business financial analysis, SWOT analysis, PEST analysis, benchmarking and key success factors analysis.

Generally, the ten most used SMTTs according to the results of several studies conducted in developing countries (Ghamdi, 2005; Dincer, Tatoglu and Glaister, 2006; Elbanna, 2007; Aldehayyat and Anchor, 2009; Aldehayyat, Al Khattab and Anchor, 2011; Kalkan and Bozkurt, 2013; Rajasekar and Al Raee, 2014) are: SWOT analysis, business financial analysis, PEST analysis, benchmarking, 
Porter's five forces analysis, key success factors analysis, competitor financial analysis, stakeholder analysis, strategic planning and cost-benefit analysis.

\section{Countries in transition}

None of the studies in transition countries analyze the usage of SMTTs in particular, but only as part of the strategic management process. Therefore, the research of Šuklev and Debarliev (2012) does not mention researched strategic tools, whereas Kume and Leskaj (2009) identify four most used tools in DSEs. Here again SWOT analysis leads as the most used tool.

Based on the above results, the most commonly used tools regardless of the country development level are SWOT analysis and Porter's five forces analysis. On the other hand, the most used tools in developed countries and developing countries are benchmarking, key success factors analysis and cost-benefit analysis.

It is noted that some of the tools used by enterprises in developed countries are not used in developing countries, such as customer satisfaction and "what-if" analysis.

The research results indicate that more strategic tools and techniques are used in developed countries, followed by developing countries, and the fewest are used in countries in transition.

\section{Empirical studies at global level}

Empirical research on the global level is the same as research in countries with different levels of development, which has been previously addressed in a general way. This part includes the results of the research by O'Brien (2009) which are excluded in the above analysis because we did not know the size of enterprises and sectors surveyed. 
Empirical research on the global level has been conducted by different authors (Rigby, 1993; 2001; Tapinos, 2005; O’Brien, 2009; Tassabehji and Isherwood, 2014; Rigby and Bilodeau, 2015). All the above studies focused on different enterprise sizes and sectors, excluding O'Brien (2009).

Although the number of DSEs researched by Tapinos (2005) was not large $(n=428)$, this research spanned 42 different countries. The sample size (DSE) explored by Tassabehji and Isherwood (2014) was similar $(n=458)$ with that of Tapinos (2005) and included 47 different countries. The results of this study highlighted the multidimensional aspect of strategic tools and the fact that current managers are using more categories of tools based on a traditional structural approach and much less tools that encourage and facilitate the development of new markets, products and processes, including the concept of "blue ocean".

Unlike Tassabehji and Isherwood, O'Brien (2009) points to an apparent lack of awareness of the respondents of some classic tools, including Porter's five forces analysis, with 45.19 percent of respondents answering that they had never heard of it. Also, 25.93 percent of respondents answered that they had never heard of PEST analysis and 37.04 percent had never heard of portfolio matrices.

Among studies on the global level, undoubtedly the survey with the largest sample size $(n=13,000)$ is the one conducted by Rigby and Bilodeau (2015). This kind of survey that explores the views of managers on SMTT use, the satisfaction level and the usage of SMTTs, was presented for the first time by Rigby, for Bain \& Company, in 1993 (Rigby and Bilodeau, 2007). The company today continues to investigate and analyze the use and effectiveness of 25 management tools and techniques on five continents with over 13,000 respondents in more than 70 countries in North and South America, Europe, Asia and Africa (Rigby and Bilodeau, 2015). Table 3 presents a summary of results on the ten most used tools at the global level in the period 2000-2014. 
Table 3: The Ten Most Used Tools during the Period 2000-2014

\begin{tabular}{|c|c|c|c|c|}
\hline 2000 & 2006 & 2010 & 2012 & 2014 \\
\hline $\begin{array}{l}\text { (1) Strategic } \\
\text { planning }\end{array}$ & $\begin{array}{l}\text { (1) Strategic } \\
\text { planning }\end{array}$ & (1) Benchmarking & $\begin{array}{l}\text { (1) Strategic } \\
\text { planning }\end{array}$ & (1) CRM \\
\hline $\begin{array}{l}\text { (2) Vision } \\
\text { and mission } \\
\text { statements }\end{array}$ & (2) CRM & $\begin{array}{l}\text { (2) Strategic } \\
\text { planning }\end{array}$ & (2) CRM & (2) Benchmarking \\
\hline (3) Benchmarking & $\begin{array}{l}\text { (3) Customer } \\
\text { segmentation }\end{array}$ & $\begin{array}{l}\text { (3) Vision and } \\
\text { mission statements }\end{array}$ & $\begin{array}{l}\text { (3) Employee } \\
\text { engagement } \\
\text { surveys }\end{array}$ & $\begin{array}{l}\text { (3) Employee } \\
\text { engagement } \\
\text { surveys }\end{array}$ \\
\hline (4) Outsourcing & (4) Benchmarking & (4) CRM & (4) Benchmarking & $\begin{array}{l}\text { (4) Strategic } \\
\text { planning }\end{array}$ \\
\hline $\begin{array}{l}\text { (5) Customer } \\
\text { satisfaction }\end{array}$ & $\begin{array}{l}\text { (5) Vision and } \\
\text { mission statements }\end{array}$ & (5) Outsourcing & $\begin{array}{l}\text { (5) Balanced } \\
\text { scorecard }\end{array}$ & (5) Outsourcing \\
\hline $\begin{array}{l}\text { (6) Growth } \\
\text { strategies }\end{array}$ & $\begin{array}{l}\text { (6) Core } \\
\text { competencies }\end{array}$ & $\begin{array}{l}\text { (6) Balanced } \\
\text { scorecard }\end{array}$ & $\begin{array}{l}\text { (6) Core } \\
\text { competencies }\end{array}$ & $\begin{array}{l}\text { (6) Balanced } \\
\text { scorecard }\end{array}$ \\
\hline $\begin{array}{l}(7) \text { Strategic } \\
\text { alliances }\end{array}$ & (7) Outsourcing & $\begin{array}{l}\text { (7) Change } \\
\text { management } \\
\text { programs }\end{array}$ & (7) Outsourcing & $\begin{array}{l}\text { (7) Vision and } \\
\text { mission statements }\end{array}$ \\
\hline $\begin{array}{l}\text { (8) Pay per } \\
\text { performance }\end{array}$ & $\begin{array}{l}8 \text { Business } \\
\text { process } \\
\text { reengineering }\end{array}$ & $\begin{array}{l}\text { (8) Core } \\
\text { competencies }\end{array}$ & $\begin{array}{l}\text { (8) Change } \\
\text { management }\end{array}$ & (8) SCM \\
\hline $\begin{array}{l}\text { (9) Customer } \\
\text { segmentation }\end{array}$ & $\begin{array}{l}\text { (9) Scenario and } \\
\text { contingency } \\
\text { planning }\end{array}$ & $\begin{array}{l}\text { (9) Strategic } \\
\text { alliances }\end{array}$ & (9) SCM & $\begin{array}{l}\text { (9) Change } \\
\text { management }\end{array}$ \\
\hline $\begin{array}{l}\text { (10) Core } \\
\text { competencies }\end{array}$ & $\begin{array}{l}\text { (10) Knowledge } \\
\text { management }\end{array}$ & $\begin{array}{l}\text { (10) Customer } \\
\text { segmentation }\end{array}$ & $\begin{array}{l}\text { (10) Vision and } \\
\text { mission statements }\end{array}$ & $\begin{array}{l}\text { (10) Customer } \\
\text { segmentation }\end{array}$ \\
\hline
\end{tabular}

Source: Adapted from Bain \& Company (Rigby and Bilodeau, 2015).

Table 3 and Figure 3 show that nine of the most used tools in 2012 remain the most used tools in 2014 and they are: CRM, benchmarking, employee engagement surveys, strategic planning, outsourcing, balanced scorecard, vision and mission statements, SCM and change management. Only the core competencies tool is not on the list of the ten most used tools in 2014; it has been replaced by customer segmentation. The four tools used the most during the 2000-2014 period are: benchmarking, strategic planning, outsourcing and vision and mission statements. Interestingly, employee engagement surveys as a tool are among the ten most used tools, namely third in the 2012 and 2014 results, but they are not on the list of the ten most used tools in previous research. 
Figure 3: The Ten Most Used Tools during the Period 2000-2014

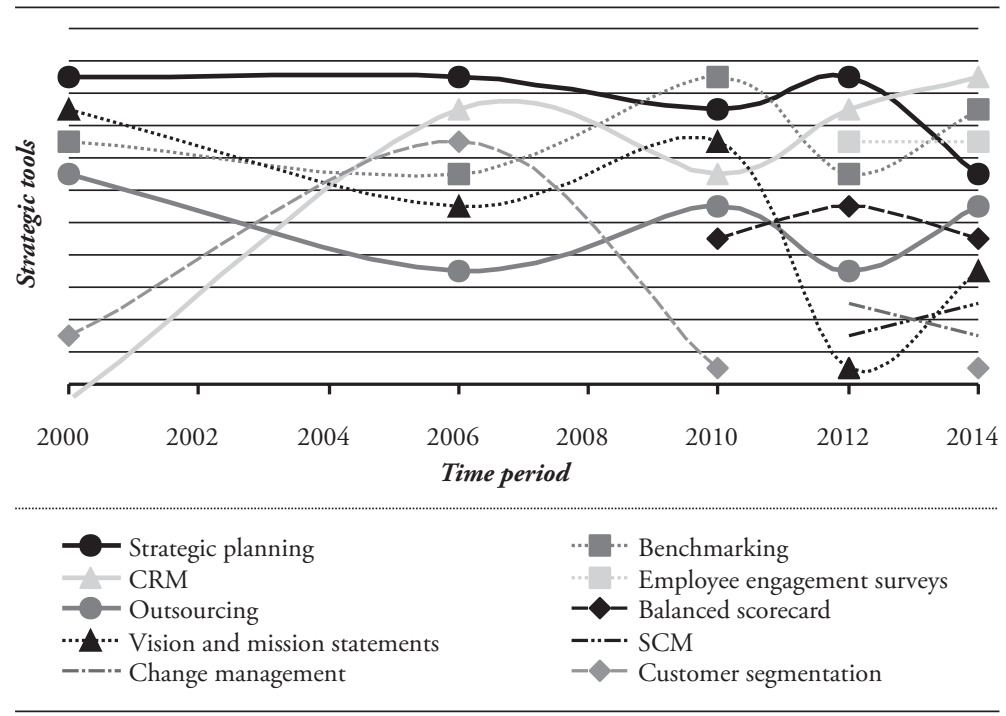

Source: Authors' calculations.

It should be noted that Bain \& Company research the 25 most used management tools globally. Within the researched tools are strategic planning and vision and mission statements. O'Brien (2009), regarding the tools and techniques explored by Rigby and Bilodeau, rightly points out that some tools on this list may seem strange; strategic planning can be considered as an integral process that includes a variety of special tools, while vision and mission statements are the products of a visioning process.

Tool use peaked in 2002, when companies used an average 16.1 tools. Overall, the use of tools has declined steadily since 2006, when 15.3 tools were used on average. The largest decline observed was after six years, more precisely in 2012, when the average use was 7.4 tools and later in 2014 it was 7.0 tools (Rigby and Bilodeau, 2015). 
This study reveals that the larger the company, the more likely it is to use the vast majority of tools. On average, large companies used 8.1 tools in 2014 compared with midsize firms that used 7.6 tools (up from 6.8 in 2012) and smaller companies that used 5.3 tools.

According to Rigby and Bilodeau (2015), regional variation in tool use is significant. China and India used the highest average number of tools in 2014 (8.0) compared with North America (7.2), Europe (6.6) and Latin America (6.2). In terms of sectors, the industries with the highest tool use are transportation and tourism, manufacturing, and technology and telecommunications.

Table 4 and Figure 4 present the most used tools according to the results of empirical studies on the global level. The results of Rigby (1993) are excluded, since they are similar to the results of Rigby and Bilodeau (2015).

Table 4: Summary of the Most Used SMTTs Derived from Empirical Studies at Global Level

\begin{tabular}{l|l:l:l}
\hline $\begin{array}{c}\text { Tapinos (2005) } \\
\text { DSE, DS }\end{array}$ & \multicolumn{1}{c}{$\begin{array}{c}\text { O'Brien (2009) } \\
\text { N/I, N/I }\end{array}$} & $\begin{array}{c}\text { Tassabehji and } \\
\text { Isherwood (2014) } \\
\text { DSE, DS }\end{array}$ & $\begin{array}{c}\text { Rigby and Bilodeau } \\
\text { (2015) }\end{array}$ \\
DSE, DS
\end{tabular}

Source: Authors' construction. 
Figure 4: The Most Used SMTTs Derived from Empirical Studies at Global Level

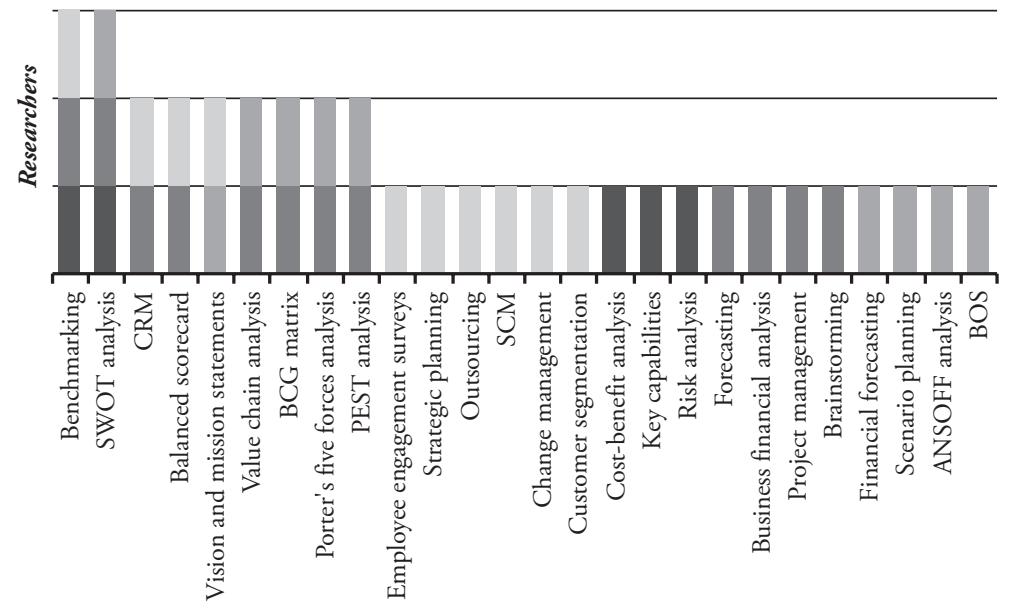

Tapinos (2005)

Tassabehji and Isherwood (2014)
O'Brien (2009)

Rigby and Bilodeau (2015)

Source: Authors' calculations.

Table 4 and Figure 4 show the 26 tools that proved to be the most used tools according to four empirical studies on the global level. It is interesting to note that no tool turned out to be the most used one amongst all research studies in question. Benchmarking and SWOT analysis proved to be the most used tools according to the results of three different studies. We must emphasize that SWOT analysis cannot be found among the ten most commonly used tools in the research of Rigby and Bilodeau (2015), while in three other studies it was. Benchmarking and SWOT analysis are followed by the tools identified as most used in two different studies: CRM, balanced scorecard, vision and mission statements, value chain analysis, BCG matrix, Porter's five forces analysis and PEST/EL analysis. 
In addition, we must note that within the results of Rigby and Bilodeau (2015), not only is SWOT analysis missing, but so are classic strategic management tools such as BCG matrix, Porter's five forces analysis and PEST/EL analysis. In fact, such tools are not even included in the list of investigated tools, while they appear as the most used ones in many other empirical studies.

In general, it can be concluded that the results for the ten most used tools from Rigby and Bilodeau (2015) share only two same tools with the outcomes of the ten most used tools from all other empirical research. These are benchmarking and vision and mission statements.

\section{Conclusion}

There is no doubt that strategic management tools and techniques are important parts of the strategic management process. They are designed to support managers in all stages of the strategic management process. However, the up-to-date research on these strategic tools and techniques pertains mainly to the level of their usage and classification. Thus, there has already been a highlight by academics on the need to review the role and importance of strategic management tools and techniques. Hence, this study serves to fill the existing gap between theoretical constructs and the evidence of practical usage of strategic management tools and techniques in enterprises.

The results of this study will add value to practitioners and scholars in the field of strategic management. The findings from this study may be utilized to maximize the full potential of enterprises and reduce the cases of entrepreneurship failures, through creating awareness of the importance of using strategic management tools and techniques. Finally, this study contributes to the field of strategic management: it summarizes the most used strategic tools and techniques at the global level according to sectors and varying stages of countries' economic development. 
Some empirical studies have been focused on surveying the level of satisfaction with SMTT usage in different enterprises (Ghamdi, 2005; Gunn and Williams, 2007; Aldehayyat and Anchor, 2009; Rigby and Bilodeau, 2013; 2015). This study does not deepen this aspect, so it is suggested to be investigated in the future. Another limitation of this study is that it does not include empirical studies for a particular tool or technique usage, but only articles about strategic tools and techniques usage as empirical evidence in different countries.

\section{Literature}

Afonina, Anna, 2015, "Strategic Management Tools and Techniques and Organizational Performance: Findings from the Czech Republic", Journal of Competitiveness, 7(3), pp. 19-36. https://doi.org/10.7441/joc.2015.03.02

Afonina, Anna and Vladimír Chalupský, 2012, "The Current Strategic Management Tools and Techniques: The Evidence from Czech Republic", Economics and Management, 17(4), pp. 1535-1544. https://doi.org/10.5755/j01. em.17.4.3026

Afonina, Anna and Vladimír Chalupský, 2013, "Investigation of Strategic Management Tools and Techniques", Acta Universitatis Agriculturae et Silviculturae Mendelianae Brunensis, 61(4), pp. 833-840. https://doi.org/10.11118/ actaun201361040833

Aldehayyat, Jehad S., Adel A. Al Khattab and John R. Anchor, 2011, "The Use of Strategic Planning Tools and Techniques by Hotels in Jordan", Management Research Review, 34(4), pp. 477-490. https://doi.org/10.1108/01409171111117898

Aldehayyat, Jehad S. and John R. Anchor, 2009, "Strategic Planning Tools and Techniques in Jordan: Awareness and Use", Strategic Change, 17(7-80), pp. 281293. 
Baldridge, David C., Steven W. Floyd and Lívia Markóczy, 2004, “Are Managers from Mars and Academicians from Venus? Toward an Understanding of the Relationship between Academic Quality and Practical Relevance", Strategic Management Journal, 25(11), pp. 1063-1074, cited by Jarzabkowski et al., 2012. https://doi.org/10.1002/smj.406

Barney, Jay, 1991, "Firm Resources and Sustained CompetitiveAdvantage", Journal of Management, 17(1), pp. 99-120. https://doi.org/10.1177/014920639101700108

Barney, Jay B. and Delwyn N. Clark, 2007, Resource-Based Theory: Creating and Sustaining Competitive Advantage, Oxford: Oxford University Press.

Bélanger, Emmanuelle, Charo Rodríguez and Danielle Groleau, 2011, "Shared Decision-Making in Palliative Care: A Systematic Mixed Studies Review Using Narrative Synthesis", Palliative Medicine, 25(3), pp. 242-261. https://doi. org/10.1177/0269216310389348

Berisha, Gentrit and Justina Shiroka Pula, 2015, "Defining Small and Medium Enterprises: A Critical Review”, Academic Journal of Business, Administration, Law and Social Sciences, 1(1), pp. 17-28.

Berisha Qehaja, Albana, Enver Kutllovci and Justina Shiroka Pula, 2017, "Strategic Management Tools and Techniques Usage: A Qualitative Review", Acta Universitatis Agriculturae et Silviculturae Mendelianae Brunensis, 65(2), pp. 585-600. https://doi.org/10.11118/actaun201765020585

Berry, Maureen, 1998, "Strategic Planning in Small High Tech Companies", Long Range Planning, 31(3), pp. 455-466. https://doi.org/10.1016/S00246301(98)80012-5

Bower, Joseph L., 2008, "The Teaching of Strategy: From General Manager to Analyst and Back Again?”, Journal of Management Inquiry, 17(4), pp. 269-275, cited by Jarzabkowski et al., 2012. https://doi.org/10.1177/1056492608318149

Carter, Chris, Stewart R. Clegg and Martin Kornberger, 2008, "Strategy as Practice", Strategic Organization, 6(1), pp. 83-99. https://doi. org/10.1177/1476127007087154 
Clark, Delwyn N., 1997, "Strategic Management Tool Usage: A Comparative Study”, Strategic Change, 6(7), pp. 417-427. https://doi.org/10.1002/(SICI)10991697(199711)6:7<417::AID-JSC281>3.0.CO;2-9

Clark, Delwyn N. and John L. Scott, 1999, "Strategic Level MS/OR Tool Usage in the United Kingdom and New Zealand: A Comparative Survey", Asia-Pacific Journal of Operational Research, 16(1), pp. 35-51.

Dagnino, Giovanni Battista and Maria Cristina Cinici, eds., 2016, Research Methods for Strategic Management, New York; NY: Routledge, Taylor and Francis Group.

Dincer, Omer, Ekrem Tatoglu and Keith W. Glaister, 2006, "The Strategic Planning Process: Evidence from Turkish Firms", Management Research News, 29(4), pp. 206-219. https://doi.org/10.1108/1409170610665068

Elbanna, Said, 2007, "The Nature and Practice of Strategic Planning in Egypt", Strategic Change, 16(5), pp. 227-243. https://doi.org/10.1002/jsc.797

Elbanna, Said, 2008, "Planning and Participation as Determinants of Strategic Planning Effectiveness: Evidence from the Arabic Context", Management Decision, 46(5), pp. 779-796. https://doi.org/10.1108/00251740810873761

Frost, Frederick A., 2003, "The Use of Strategic Tools by Small and MediumSized Enterprises: An Australasian Study”, Strategic Change, 12(1), pp. 49-62. https://doi.org/10.1002/jsc.607

Geddes, John and Stuart Carney, 2002, Systematic Reviews and Meta-analyses: Evidence in Mental Health Care, London: Rutledge.

Ghamdi, Salem M., 2005, "The Use of Strategic Planning Tools and Techniques in Saudi Arabia: An Empirical Study", International Journal of Management, 22(3), pp. 376-395.

Ghoshal, Sumantra and Peter Moran, 1996, "Bad for Practice: A Critique of the Transaction Cost Theory”, Academy of Management Review, 21(1), pp. 13-47, cited by Jarzabkowski et al., 2012. 
Gică, Oana Adriana and Cristina Ioana Balint, 2012, "Planning Practices of SMEs in North-Western Region of Romania-An Empirical Investigation", Procedia Economics and Finance, 3, pp. 896-901. https://doi.org/10.1016/S22125671(12)00247-X

Glaister, Keith W., Omer Dincer, Ekrem Tatoglu and Mehmet Demirbag, 2009, "A Comparison of Strategic Planning Practices in Companies from the UK and Turkey", Journal of Management Development, 28(4), pp. 361-379. https://doi. org/10.1108/02621710910947380

Glaister, Keith W. and J. Richard Falshaw, 1999, "Strategic Planning: Still Going Strong?”, Long Range Planning, 32(1), pp. 107-116. https://doi.org/10.1016/ S0024-6301(98)00131-9

Golsorkhi, Damon, Linda Rouleau, David Seidl and Eero Vaara, eds., 2010, Cambridge Handbook of Strategy as Practice, Cambridge: Cambridge University Press.

Grant, Robert M., 1991, “The Resource-Based Theory of Competitive Advantage: Implications for Strategy Formulation", California Management Review, 33(3), pp. 114-135. https://doi.org/10.2307/41166664

Grant, Robert M., 2008, "Why Strategy Teaching Should Be Theory Based", Journal of Management Inquiry, 17(4), pp. 276-281, cited by Jarzabkowski et al., 2012. https://doi.org/10.1177/1056492608318791

Grint, Keith, 1997, Fuzzy Management: Contemporary Ideas and Practices at Work, Oxford: Oxford University Press. https://doi.org/10.1093/acprof:o so/9780198775003.001.0001

Gunn, Rod and Wil Williams, 2007, "Strategic Tools: An Empirical Investigation into Strategy in Practice in the UK", Strategic Change, 16(5), pp. 201-216. https:// doi.org/10.1002/jsc.799

Hussey, David E., 1997, Strategic Management: From Theory to Implementation, Oxford: Butterworth-Heinemann. 
Jarzabkowski, Paula, 2004, "Strategy as Practice: Recursiveness, Adaptation, and Practices-in-Use", Organization Studies, (25)4, pp. 529-560. https://doi. org/10.1177/0170840604040675

Jarzabkowski, Paula, 2005, Strategy as Practice: An Activity Based Approach, London: Sage.

Jarzabkowski, Paula, Monica Giulietti, Bruno Oliveira and Nii Amoo, 2012, “'We Don't Need No Education'-Or Do We? Management Education and Alumni Adoption of Strategy Tools", Journal of Management Inquiry, 22(1), pp. 4-24. https://doi.org/10.1177/1056492612460588

Jarzabkowski, Paula and Sarah Kaplan, 2015, "Strategy Tools-in-Use: A Framework for Understanding 'Technologies of Rationality' in Practice”, Strategic Management Journal, 36(4), pp. 537-558. https://doi.org/10.1002/smj.2270

Jarzabkowski, Paula and Andreas Paul Spee, 2009, "Strategy-as-Practice: A Review and Future Directions for the Field", International Journal of Management Reviews, 11(1), pp. 69-95. https://doi.org/10.1111/j.1468-2370.2008.00250.x

Jarzabkowski, Paula and Richard Whittington, 2008, "A Strategy-as-Practice Approach to Strategy Research and Education", Journal of Management Inquiry, 17(4), pp. 282-286, cited by Jarzabkowski et al., 2012. https://doi. org/10.1177/1056492608318150

Johnson, Gerry, 2007, Strategy as Practice: Research Directions and Resources, Cambridge: Cambridge University Press. https://doi.org/10.1017/ CBO9780511618925

Kalkan, Adnan and Özlem Çetinkaya Bozkurt, 2013, "The Choice and Use of Strategic Planning Tools and Techniques in Turkish SMEs According to Attitudes of Executives", Procedia - Social and Behavioral Sciences, 99, pp. 10161025. https://doi.org/10.1016/j.sbspro.2013.10.575

Knott, Paul, 2006, "A Typology of Strategy Tool Applications", Management Decision, 44(8), pp. 1090-1105. https://doi.org/10.1108/00251740610690630 
Kotler, Philip, Roland Berger and Nils Bickhoff, 2015, The Quintessence of Strategic Management, Berlin, Heidelberg: Springer.

Kume, Vasilika and Etleva Leskaj, 2009, "Strategic Management Aspects in Albanian Companies”, JEL Classification, 28(4), pp. 717-843.

Lisiński, Marek and Mark Šaruckij, 2006, "Principles of the Application of Strategic Planning Methods", Journal of Business Economics and Management, 7(2), pp. 37-43.

Nedelko, Zlatko, Vojko Potocan and Marina Dabic, 2015, "Current and Future Use of Management Tools", E + M Ekonomie a Management, 18(1), pp. 28-45. https://doi.org/10.15240/tul/001/2015-1-003

O'Brien, Frances, 2009, "Supporting the Strategy Process: A Survey of UK OR/ MS Practitioners", Journal of the Operational Research Society, 62(5), pp. 900 920. https://doi.org/10.1057/jors.2011.2

Pasanen, Mika, 2011, "Strategic Management Tools and Techniques in SMEs", Society of Interdisciplinary Business Research (SIBR) 2011 Conference on Interdisciplinary Business Research, https://papers.ssrn.com/sol3/papers. cfm?abstract_id=1867897\# (accessed October 26, 2016).

Popay, Jennie, Helen Roberts, Amanda Sowden, Mark Petticrew, Lisa Arai, Mark Rodgers, Nicky Britten, Katrina Roen and Steven Duffy, 2006, Guidance on the Conduct of Narrative Synthesis in Systematic Reviews: A Product from the ESRC Methods Programme, https://www.researchgate.net/publication/308362339_ Guidance_on_the_conduct_of_narrative_synthesis_in_systematic_reviews (accessed December 2, 2016).

Porter, Michael E., 1991, "Towards a Dynamic Theory of Strategy", Strategic Management Journal, 12(S2), pp. 95-117. https://doi.org/10.1002/ smj. 4250121008

Porter, Michael E., 1996, "What is Strategy?", Harvard Business Review, 74(6), pp. 61-78. 
Prahalad, Coimbatore K. and Gary Hamel, 1994, "Strategy as a Field of Study: Why Search for a New Paradigm?”, Strategic Management Journal, 15(S2), pp. 5-16, cited by Jarzabkowski et al., 2012. https://doi.org/10.1002/smj.4250151002

Prescott, John E. and John H. Grant, 1988, “A Manager’s Guide for Evaluating Competitive Analysis Techniques", Interfaces, 18(3), pp. 10-22. https://doi. org/10.1287/inte.18.3.10

Rajasekar, James and Arooj Al Raee, 2014, “Organizations' Use of Strategic Planning Tools and Techniques in the Sultanate of Oman", International Business Research, 7(3), pp. 159-177. https://doi.org/10.5539/ibr.v7n3p159

Ramanujam, Vasudevan, Niloufer Venkatraman and John C. Camillus, 1986, "Multi-objective Assessment of Effectiveness of Strategic Planning: A Discriminant Analysis Approach", Academy of Management Journal, 29(2), pp. 347-372. https://doi.org/10.2307/256192

Rigby, Darrell and Barbara Bilodeau, 2007, "Bain’s Global 2007 Management Tools and Trends Survey", Strategy \& Leadership, 35(5), pp. 9-16. https://doi. org/10.1108/10878570710819161

Rigby, Darrell and Barbara Bilodeau, 2013, Management Tools \& Trends 2013, London: Bain \& Company.

Rigby, Darrell and Barbara Bilodeau, 2015, Management Tools \& Trends 2015, London: Bain \& Company.

Rigby, Darrell K., 1993, "How to Manage the Management Tools", Planning Review, 21(6), pp. 8-15. https://doi.org/10.1108/eb054443

Rigby, Darrell K., 2001, "Putting Tools to the Test: Senior Executives Rate 25 Top Management Tools", Strategy \& Leadership, 29(3), pp. 4-12. https://doi. org/10.1108/10878570110396086 
Stenfors, Sari, Leena Tanner, Mikko Syrjänen, Tomi Seppälä and Ilkka Haapalinna, 2007, "Executive Views Concerning Decision Support Tools", European Journal of Operational Research, 181(2), pp. 929-938. https://doi. org/10.1016/j.ejor.2006.06.024

Stonehouse, George and Jonathan Pemberton, 2002, "Strategic Planning in SMEs-Some Empirical Findings", Management Decision, 40(9), pp. 853-861. https://doi.org/10.1108/00251740210441072

Šuklev, Bobek and Stojan Debarliev, 2012, "Strategic Planning Effectiveness Comparative Analysis of the Macedonian Context", Economic and Business Review for Central and South-Eastern Europe, 14(1), pp. 63-93.

Tapinos, Efstathios, 2005, "Strategic Development Process: Investigating the Relationship between Organisational Direction and Performance Measurement”, doctoral dissertation, University of Warwick.

Tassabehji, Rana and Andrew Isherwood, 2014, "Management Use of Strategic Tools for Innovating during Turbulent Times", Strategic Change, 23(1-2), pp. 63-80. https://doi.org/10.1002/jsc.1960

Vaara, Eero and Richard Whittington, 2012, "Strategy-as-Practice: Taking Social Practices Seriously", The Academy of Management Annals, 6(1), pp. 285336, cited by Berisha Qehaja, Kutllovci and Shiroka Pula, 2017. https://doi.org/ $10.1080 / 19416520.2012 .672039$

Vaitkevičius, Sigitas, 2006, "Modelling of Strategic Analysis in Strategic Management", Engineering Economics, 4(49), pp. 37-47.

Vaitkevičius, Sigitas, 2007, "Application of Strategic Management Tools in Lithuania: Managers' Knowledge and Experience", Engineering Economics, 4(54), pp. 70-77.

Webster, James L., William E. Reif and Jeffrey S. Bracker, 1989, “The Manager's Guide to Strategic Planning Tools and Techniques", Planning Review, 17(6), pp. 4-48. https://doi.org/10.1108/eb054273 
Whittington, Richard, 1996, "Strategy as Practice", Long Range Planning, 29(5), pp. 731-735. https://doi.org/10.1016/0024-6301(96)00068-4

Whittington, Richard, 2006, "Completing the Practice Turn in Strategy Research”, Organization Studies, 27(5), pp. 613-634. https://doi. org/10.1177/0170840606064101

Whittington, Richard, 2012, "Big Strategy/Small Strategy", Strategic Organization, 10(3), pp. 263-268. https://doi.org/10.1177/1476127012452828

Whittington, Richard, Paula Jarzabkowski, Michael Mayer, Eléonore Mounoud, Janine Nahapiet and Linda Rouleau, 2003, "Taking Strategy Seriously: Responsibility and Reform for an Important Social Practice", Journal of Management Inquiry, 12(4), pp. 396-409, cited by Jarzabkowski et al., 2012. https://doi.org/10.1177/1056492603258968

World Bank, 2014, World Economic Situation and Prospects, http://unctad.org/ en/PublicationsLibrary/wesp2014_en.pdf (accessed November 11, 2016).

Wright, Robert P., Sotirios E. Paroutis and Daniela P. Blettner, 2013, "How Useful Are the Strategic Tools We Teach in Business Schools?", Journal of Management Studies, 50(1), pp. 92-125. https://doi.org/10.1111/j.1467-6486.2012.01082.x 